THE SOCIOECONOMIC DIMENSIONS

OF

HIV/AIDS IN AFRICA

$\overline{x \times x \times x}$ 


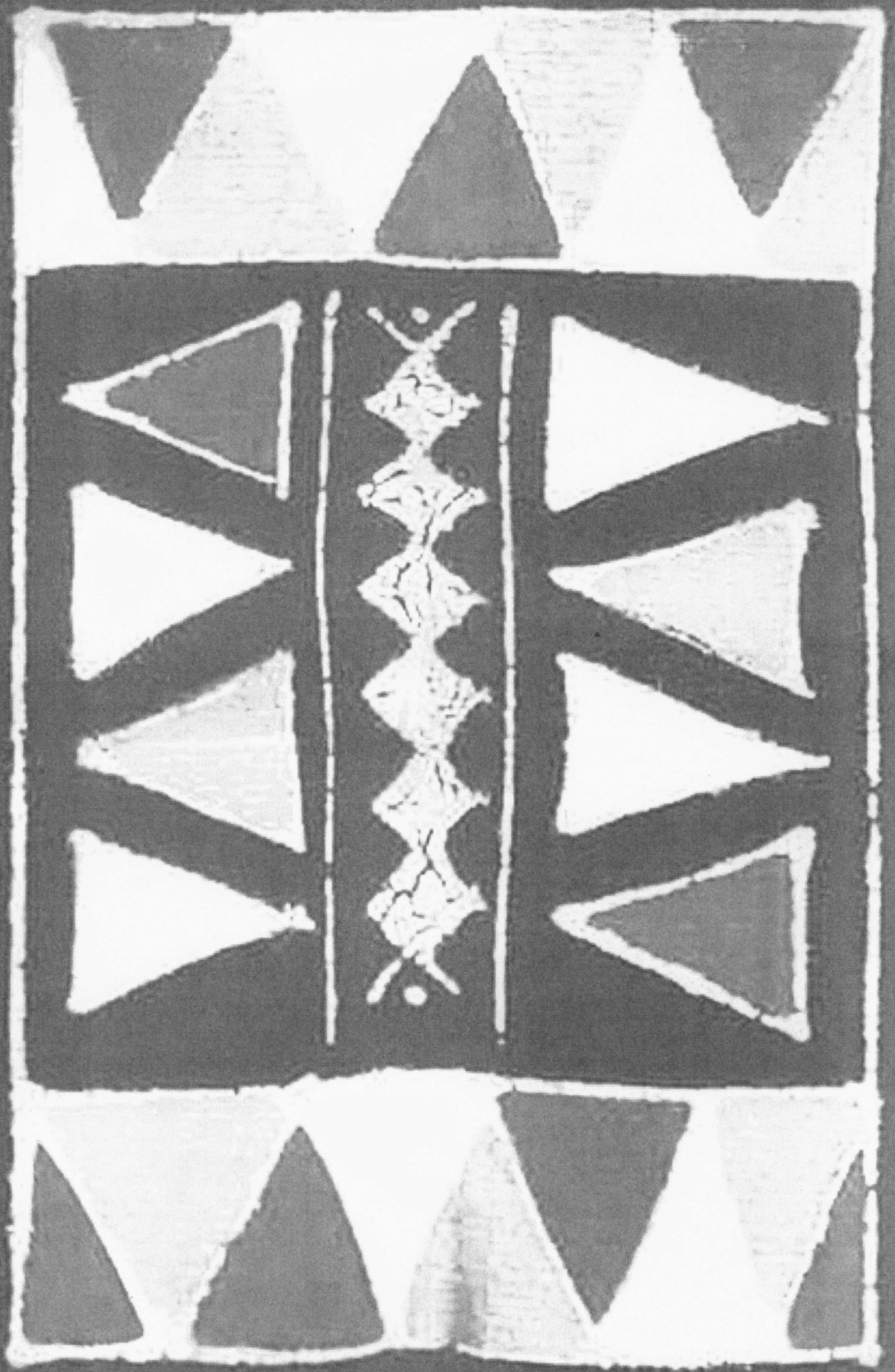




\title{
THE SOCIOECONOMIC DIMENSIONS OF
}

\section{HIV/AIDS IN AFRICA}

Challenges, Opportunities, and Misconceptions

\author{
edited by \\ DAVID E. SAHN
}

PUBLISHED IN COOPERATION

WITH THE

UNITED NATIONS UNIVERSITY

CORNELL UNIVERSITY PRESS ITHACA AND LONDON 


\section{Copyright $\odot 2010$ by Cornell University}

All rights reserved. Except for brief quotations in a review, this book, or parts thereof, must not be reproduced in any form without permission in writing from the publisher. For information, address Cornell University

Press, Sage House, 512 East State Street, Ithaca, New York 14850.

First published 2010 by Cornell University Press in cooperation with the United Nations University

Printed in the United States of America

\section{Library of Congress Cataloging-in-Publication Data}

The socioeconomic dimensions of HIV/AIDS in Africa : challenges, opportunities, and misconceptions / edited by David E. Sahn.

p. $\mathrm{cm}$.

"Published in cooperation with the United Nations University."

Includes bibliographical references.

ISBN 978-0-8014-7693-8 (pbk. : alk. paper)

1. AIDS (Disease)-Social aspects-Africa, Sub-Saharan.

2. AIDS (Disease)-Economic aspects-Africa, Sub-Saharan.

3. HIV infections-Economic aspects-Africa, Sub-Saharan.

4. HIV infections-Social aspects-Africa, Sub-Saharan.

I. Sahn, David E. II. United Nations University. III. Title.

RA643.86.A357s63 2010

$362.196^{\prime} 97920096-\mathrm{dc22}$

2010033351 